\title{
PENGARUH BUDAYA ORGANISASI, MOTIVASI, DAN KOMPENSASI TERHADAP PRODUKTIVITAS KERJA KARYAWAN ADMINISTRATIF UNIVERSITAS ISLAM INDONESIA
}

Oleh:

Arief Darmawan, SE.,MM")

Penelitian ini bertujuan untuk menngetahui apakah Budaya organisasi, Kompensasi, dan Motioasi secara parsial dan bersama-sama berpengaruh terhadap produktivitas karyawan administratif di Universitas Islam Indonesia dan variabel apakah yang paling berpengaruh terhadap produktivitas kerja karyawan administratif di Universitas Islam Indonesia?...-

Metode sampling yang ditempuh adalah dengan menggunakan teknik pengambilan sampel secara acak sederhana (Simple Random Sampling), data primer dikumpulkan menggunakan kuesioner. Jumlah sampel minimal dalam penelitian ini yang harus diambil minimal 82 orang. Analisis Data dildkukan dengan menggunakan Regresi Linera Berganda, dan diolah menngunakan Software SPSS 10.0 for Windows

Dari hasil penelitian dapat diambil kesimpulan umum bahwa: secara parsial Budaya organisasi dan kompensasi tidak berpengaruh terhadap produktivitas kerja. Motioasi berpengaruh signifikan terhadap produktivitas kerja. Secara bersamasama budaya organisasi, kompensasi dan motivasi memiliki pengaruh yang signifikan terhadap produktivitas kerja karyawan administratif di Universitas. Islam Indonesia. Dari ketiga variabel yang mempengaruhi produktivitas, Motivasi merupakan variabel yang berpengaruh paling dominan terhadap produktivitas kerja.

Kata Kunci: Budaya Organisasi, Motivasi, Kompensasi, Produktivitas Kerja

\section{A. PENDAHULUAN}

-Institusi pendidkan di Indonesia pada umunya dan Jogjakarta pada khususnya saat ini menghadapi persaingan yang semakin keras. Kompetisi : untuk dapat memenangkan persaingan tidak hanya berlangsung antar Institusi pendidikan dalam negeri saja. Masuknya institusi pendidikan asing juga meningkatkan persaingan dan harus menjadi salah satu pertimbangan institusi

") Arief Darmawan, SE.,MM adalah Dósen Program Diploma 3 Fäkultas Ekonomi Universitas Islam Indónesia. 
pendidikan dalam negri dalam menentukan strategi organisasinya. Untuk itu intitusi pendidikan dituntut dapat menyesuaikan diri dengan kondisi yang telah berubah dengan cepat tersebut (Budiyati, 2006). Universitas Islam Indonesia sebagai salàh satu bentuk industri jasa juga merasakan dampak tuntutan akan kenggulan kompetitif

Untuk tetap menjaga kesinambungan sebuah organisasi mensyaratkan . kesiapan sumber daya manusia yang berkualitas. Demikian juga dengan Universitas Islam indonesia sebagai salah satu institusi yang bertanggungjawab terhadap penyiapan SDM yang berkualitas mengharuskan Ull untuk terlebih dahulu menyiapkan dirinya baik karyawan edukatif maupun administratif. Untuk itu pengelolaan manajemen SDM tidak bisa diabaikan begitu saja, karena ketersediaan SDM yang berkualitas pada akhimya akan membawa produktivitas karyawan secara optimal.

Manusia sebagai salah satu bagian organiasi atau perusahaan dan penggerak kegiatan perusahaan yang merupakan sumber daya dalam kegiatan organisasi, juga merasakan dampak upaya organisasi yang melakukan penyesuaian dengan lingkungannya. Dengan keunggulan dan kemampuan yang dimilikinya, manusia dapat menjadi faktor penentu kelebihan suatu organisai terhadap organisasi yang lainnya.

Produktivitas manusia menjadi penting untuk membantu tercapainya usaha organisasi menjadi efektif dan efisien. Kinerja organisasi yang efektif dan efisien akan membantu organisasi dalam bersaing dengan organisai lainnya. Hingga perusahaan harus berupaya mendorong agar produktiivtas sumber daya manusia yang ada didalam perusahaan menjadi lebih baik.

Banyak faktoryang dapàt mempengaruhi produktivitas tenaga kejja secara umum. Kotter dan Hessket mengatakan bahwa budaya organisasi diyakini merupakan faktor penentu terhadap kesuksesan kinerja ekonomi suatu organisasi (Munandar dalam Budiyati, 2006). Budaya organisasi yang kuat, dinamis dan adaptif merupakan model budaya organisasi yang ideal untuk suatu organisasi (Lako, 2002). Budaya yang kuat akan mampu mengikat dan mempengaruhi perilaku individu sehingga pelaku organisasi mampu mencapai tujuan. Budaya organisasi yang dinamis dan adaptif akan membuat organisasi bersifat fleksibel dan responsif terhadap perubahan dan perkembangan lingkungan internal aupun eksternal.

Beberapa penelitian terdahulu yang menjadi acuan dan mengulas mengenai produktivitas kerja karyawan adalah Mulyono (1998), yang mengkaitkan variabel pendidikan dan motivasi terhadap produktivitas kerja karyawan perguruan tinggi swasta di Jogjakarta dan penelitian Haryani (1998) yang mengkaitkan kepuasan kerja terhadap produktivitas kerja karyawan perusahaan tenun setagen di Jogjakarta berdasarkan studi empirik di atas, maka pengembangan yang dilakukan terhadap penelitian ini adalah menambah variabel budaya organisasi, kompensasi, dan motivasi produktivitas kerja dengan objek penelitiannya adalah Karyawan Administratif pada Universitas Islam Indonesia.

Pengambilan karyawan Administratif sebagai sampel penelitian ini dilakukan dengan pertimbangan, bahwa produktivitas kerja mereka akan sangat mempengaruhi keberhasilan institusi pendidikan dalam menjalankan Catur Dama Perguruan Tinggi, yaitu memberikan layanan terbaik pada stakeholdemya. 
Arief Darmawan: Pengaruh Budaya Organisasi, Motivasii, dam HSormpemsasii ...

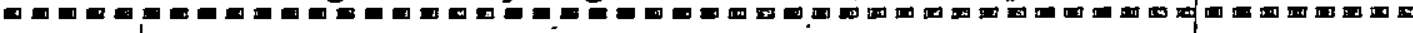

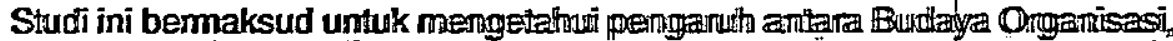
kompensasi, dan motivasiterthardap prodtudktingitias.

\section{B. RUMUSAN MASALAH}

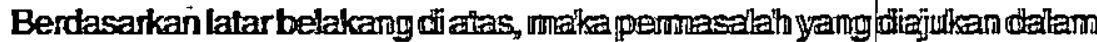
penelitian ini adalah:

1. Apakah Budaya organisasi, Kormpensasi, dan Motivasi secara parsial berpengaruh terhadap produkdivitas ikenrawan adrministratif ofi Universites Islam Indonesia?

2 Apakah Budaya organisasi, Kompensasi, dan Mofivasisecarabersam sama berpengaruh ferhadap produlkfiyutas karyansan administrafif of Universitas Islam Indonesia?

3. Variabel apakah yang paling berpengaruth terthactap produlkcijütas tkaryawan administratif di Universitas Islam Indonesia?

\section{TUJUAN PENELTIAN}

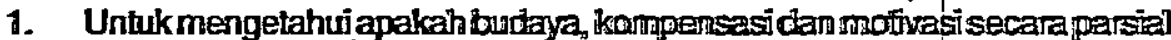
berpengaruh terhadap produktivitas karyaman Administraiti di Universitas Islam Indonesia

2. Untuk mengetahui apakah budaya, lkompensasi dan unolivasi secara bersama-sama berpengaruh tertadap produkfintas kenyanan Administretif di Universitas Islam Indonesia

3. Untuk mengetahui variabel apakah yang paifing bergengavih terthadep produktivitas karyanan Administraff of Uninersitas islam indonesia

D. KERANGKA PIKIR DAN PENGEMBANGAN HIPOTESIS

Berpijak dari temuan-tersuan empiris yang dillakukas olek penefin sebelumnya serta teori-teori penculuing yang relevan, maka penelifian ini menurunkan kerangka pikir sebagai berikuut:

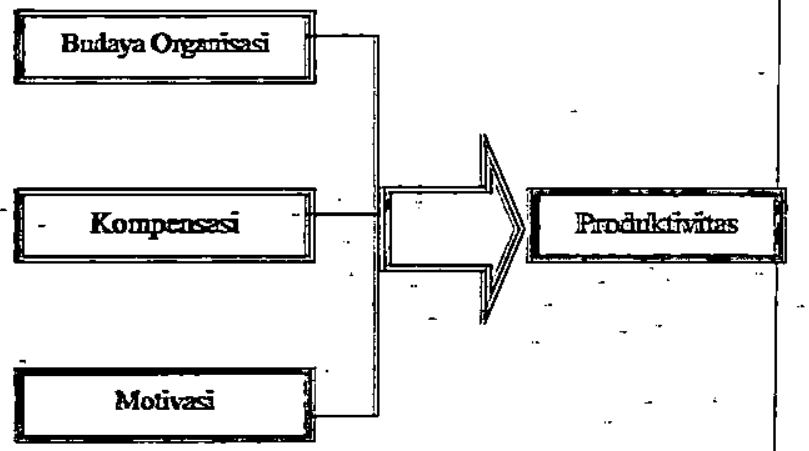

Gambar 1 : Kerangka Pikir 
Kerangka pikir penelitian di depan menjelaskan bahwa produktifitas karyawan administratif di Universitas Islam Indonesia di pengaruhi oleh variabelvariabel antara lain budaya organisasi, kompensasi dan motivasi karyawan.

- Penelitian ini diharapkan dapat membuktikan hipotesis sebagai berikut :

1. Budaya Organisasi berpengaruh positif dan signifikan terhadap Produktivitas karyawan

2. Motivasi berpengaruh positif dan signifikan terhadap Produktivitas karyawan

3. Kompensasi berpengaruh positif dan signifikan terhadap Produktivitas karyawan

4. Budaya Organisasi, Motivasi, Kompensasi secara bersama-sama berpengaruh positif dan signifikan terhadap Produktivitas kanyawan

5. Terdapat variabel yang dominan berpengaruh terhadap produktivitas kerja

\section{E. PENELITIAN SEBELUMNYA}

Penelitian Mulyono dengan Judul" Analisis Faktor-faktor Motivasi dalam Produktivitas Kerja Karyawan, Perguruan Tinggi Swasta Kpotertis V Propinsi Daerah Istimewa Jogjakarta" bertujuan untuk menganalisis hubungan antara faktor-faktor motivasi dengan produktivitas kerja para karyawan. Peneliti mendapatkan temuan empiris bahwa $92 \%$ penyebab naik turunnya produktivitas kerja karyawan dipengaruhi oleh Motivasi kerja, loyalitas, tingkat pendidikan, pengalaman kerja dan lingkungan kerja. Sedangkan $8 \%$ sisanya disebabkan oleh faktor-faktor lain yang tidak tercakup dalam penelitian ini.

Penelitian Ariyanti dengan Judul “ Analisis Budaya Organisasi, Kepuasan Gaji, Kepuasan kerja, gender dan Pendidikan dalam Produktivitas Kerja Staf Akunting" : Studi Empiris" bertujuan untuk menguji dan mengidentifikasikan kembali hubungan yang signifikan antara budaya organisasi dengan kepuasan gaji, hubungan yang signifikan antara budaya organisasi dengan motivasi, dan hubungan yang signifikan antara budaya organisasi dengan latar belakang pendidikan. Penelitian tersebut menghasilkan beberapa temuan empiris yaitu: 1) Terdapat hubungan antara budaya organisasi dengan kepuasan gaji, 2) terdapat hubungan antara Budaya organisasi dengan motivasi, 3) terdapat hubungan antara Budaya Organisasi dengan latar belakang pendidikan, penelitian ini juga menunjukkan adanya hubungan antara Budaya organisasi dengan Kepuasan gaji, Motivasi dan latar belakang pendidikan terhadap Produktivitas.

\section{F. METODE PENELITIAN}

\section{Variabel Penelitian}

Variabel "untuk penelitan ini terdiri dari empat variabel yang diklasifikasikan sebagai berikut : Variabel independen yaitu : budaya organisasi,.motivasi dan kompensasi. Sedangkan variabel dependen yaitu : produktivitas keja karyawan. 
Arief Darmawan: Pengaruh Budaya Organisasi, Motivasi, dan Kompensasi ...

\section{Populasi dan Pemilihan Sampel}

Populasi pada penelitian ini adalah seluruh tenaga tetap administratif atau karyawan yayasan di Universitas Isiam Indonesia Jogjakarta yang terdiri, karyawan administratif, kepala-kepala divisi, dan kepala urusan dan tersebar pada berbagai unit-unit organisasi, baik pada level universitas maupun fakultas Jumlah karyawan tetap administratif adalah sebanyak 386 (Biro SDM ỤII, 2007).

\section{Teknik Pengambilan Sampel}

Metode sampling yang ditempuh adalah dengan menggunakan teknik pengambilan sampel secara acak sederhana (Simple Random Sampling), dimana setiap anggota populasi mempunyai peluang yang sama untuk dipilih menjadi anggota sampel. Jumlah sampel minimal yang harus diambil dalam penelitian ini mengacu pada pendapat Solvin dalam Umar (2001) dengan menggunakan rumus $\mathrm{n}=\mathrm{N} / \mathrm{i}+\mathrm{Ne}^{2}$. dimana :

$\mathrm{n}=$ ukuran sampel

$\mathrm{N}=$ Ukuran populasi

$\mathrm{e}=$ Prosentase kelonggaran ketidaktelitian karena kesalahan pengambilan sampel yang dapat ditolelir.

Dengan jumlah karyawan administratif sebanyak 386 orang, maka jumlah sampel minimal yang harus diambil jika diasumsikan besarnya e adalah $10 \%$ maka secara matematis jumlah sampel minimal yang harus diambil adaiah : $386 /\left(1+386 \times 0,1^{2}\right)=82$ orang.

\section{Teknik Pengumpulan Data}

a. Kuisioner

Kuisioner berisi pertanyaan yang ditujukan kepada responden, item kuisioner adalah tipe pilihan ganda dengan menggunakan slaka linkert. Responden diminta untuk memilih salah satu jawaban, setiap pertanyaan disediakan empat alternatif jawaban, yaitu : SS (Sangat Setuju), S (Setuju), RR (Ragu-Ragu), TS (Tidak Setuju) dan STS (Sangat Tidak Setuju). Setiap skor diberi jawaban numerik untuk dapat menentukan derajat favourrableness. Skor numerik atas jawaban responden tersebut terdiri atas 5 poin yaitu skor yang berurutan dari angka 1-5.. Kuisiner penelitian terdiri dari 10 Pertanyaan tentang Budaya Organisasi, 10 Pertanyaan tentang kompensasi, 10 Pertanyaan tentang Motivasi dan 20 Pertanyaan tentang Produktivitas Kerja.

\section{b. Wawancara}

Dilakukan dengan cara tanya jawab secara langsung kepada responden, apabila jawaban dari kuesioer tidak jelas.

\section{c. - Dokumentasi}

Yaitu dengan melihat data-data yang sudah ada pada obyek penelitian. 


\section{Uji Validitas}

Uji validitas digunakan untuk mendeteksi apakah alat ukur yang digunakan untuk mengumpulkan data itu benar-benar sahih atau tidak. Untuk menguji validitas digunakan teknik korelasi produk moment angka besar (Karl Pearson) dengan rumus sebagai berikut (Mustafa 2000):

$$
R_{x y}=\frac{N \sum X Y-\left(\sum X\right)\left(\sum Y\right)}{\sqrt{\left.\left.\left\{N \sum X^{2}-\left(\sum X^{2}\right)\right\}\left\{N \sum Y^{2}\right)-\sum Y^{2}\right)\right\}}}
$$

Uji validitas dalam penelitian ini dilakukan dengan program spss 10 for. windows. Pengujian ini diwali dengan melakukan uji coba instrumen penelitian atau alat ukur penelitian pada 30 responden yang memiliki karakteristik sama dan tidak termasuk dalam sampel penelitian. Langkah-langkah yạng ditempuh untuk meiakukan uji validitas adalah (Santoso 2000):

a) Menentukan hipotesis

$\mathrm{Ho}=$ Skor butir berkorelasi positif dengan skor faktor

$\mathrm{H} 1$ = Skor butir berkorelasi positif dengan skor faktor

b) Menentukan nilai r tabel

Dengan jumlah kasus sebanyak 30 maka diperoleh besarnya $\mathrm{df}=30-2=$ 28. Jika tingkat signifikansi yang dipakai adalah $5 \%$ maka besarnya $r$ adalah 0.2327

c) Mencari r hasil

r hasil pada tiap item dapat dilihat dari pada kolom corrected item-total corelation.

d) Mengambil keputusan

- Jika $r$ hasil positif, $r$ hasil $>r$ tabel, maka butir tersebut valid

- Jika $r$ hasil positif, $r$ hasil < $r$ tabel, maka butir tersebut tidak valid

Hasil try out menunjukan bahwa seluruh butir pertanyaan yang digunakan untuk mengukur variabel-variabel penelitian tidak semuanya valid yaitu butir 9 pada variabel budaya (X1), butir 7, 9 dan 10 pada variabel kompensasi (X2) dan butir 10 pada variabel motivasi (X3) Karena butir-butir pertanyaan tersebut tidak sah (Valid) dalam mengukur variabel produktifitas karyawan administratif di UII, maka untuk penyebaran kuisioner yang sesungguhnya seluruh item pertannyaan dari variabel $Y$ di keluarkan dari variabel penelitian.

Pengujian validitas pada kuisioner sesungguhnya yang berjumlah 85 responden diperoleh besamya r tabel 0,1279 ( $\mathrm{df}=85$ dan $\alpha=5 \%$ ). Hasil pengujian menunjukan terdapat satu butir pertanyaan pada variabel motivasi yang tidak valid yaitu (X3.9) sehingga untuk proses pengolahan data pada tahap berikutnya butir pertanyaan tersebut tidak dipergunakan kembali. Hasil dari pengujian 
Arief Darmawan: Pengaruh Budaya Organisasi, Motivasi, dan Kompensasi ...

validitas untuk masing- masing butir pertanyaan dari setip variabel adalah șebagaj berikut :

a. Uji Validitas Butir-butir Pertanyaan pada Variabel Produktifitas (Y)

Tabel 1

Uji Validitas Variabel Produktifitas (Y)

\begin{tabular}{|c|c|c|c|}
\hline Butir & R-stat & R-tabel & Keterangan \\
\hline Y1 & .4964 & 0,1279 & Yalid \\
\hline Y2 & .5935 & 0,1279 & Valid \\
\hline Y3 & .4592 & 0,1279 & Yalid \\
\hline Y4 & .4240 & 0,1279 & Yalid \\
\hline Y5 & .4617 & 0,1279 & Valid \\
\hline Y6 & .5664 & 0,1279 & Valid \\
\hline Y7 & .5178 & 0,1279 & Yalid \\
\hline Y8 & .4959 & 0,1279 & Valid \\
\hline Y9 & .5732 & 0,1279 & Valid \\
\hline Y10 & .4856 & 0,1279 & Valid \\
\hline Y11 & .5922 & 0,1279 & Valid \\
\hline Y12 & .5845 & 0,1279 & Valid \\
\hline Y13 & .5934 & $.0,1279$ & Valid \\
\hline Y14 & .5387 & 0,1279 & Valid \\
\hline Y15 & .5799 & 0,1279 & Valid \\
\hline Y16 & .5958 & 0,1279 & Valid \\
\hline Y17 & .5700 & 0,1279 & Valid \\
\hline Y18 & .5945 & 0,1279 & Valid \\
\hline Y19 & .4695 & 0,1279 & Valid \\
\hline Y20 &. .3756 & 0,1279 & Valid \\
\hline Y21 & .4619 & 0,1279 & Valid \\
\hline & & & \\
\hline
\end{tabular}


b. Uji Validitas Butir-butir Pertanyaan pada Variabel Budaya (X1)

Tabel 2

Uji Validitas Variabel Budaya (X1)

\begin{tabular}{|c|c|c|c|}
\hline Butir & 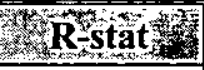 & 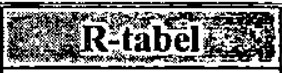 & Keterangan \\
\hline X1.1 & .5089 & 0,1279 & Valid \\
\hline $\mathrm{X} 1.2$ & .2792 & 0,1279 & Valid \\
\hline X1.3 & .3329 & 0,1279 & Valid \\
\hline $\mathrm{X} 1.4$ & .2383 & 0,1279 & Valid \\
\hline$X 1.5$ & .4077 & 0,1279 & Valid \\
\hline X1.6 & .1500 & 0,1279 & Valid \\
\hline. $\mathrm{X} 1.7$ & .2827 & 0,1279 & Valid \\
\hline $\mathrm{X} 1.8$ & .4264 & 0,1279 & Valid \\
\hline $\mathrm{X} 1.10$ & .3446 & 0,1279 & Valid \\
\hline
\end{tabular}

c. Uji Validitas Butir-butir Pertanyaan pada Variabel Kompensasi (X2)

Tabel 3

Uji Validitas Variabel Kompensasi (X2)

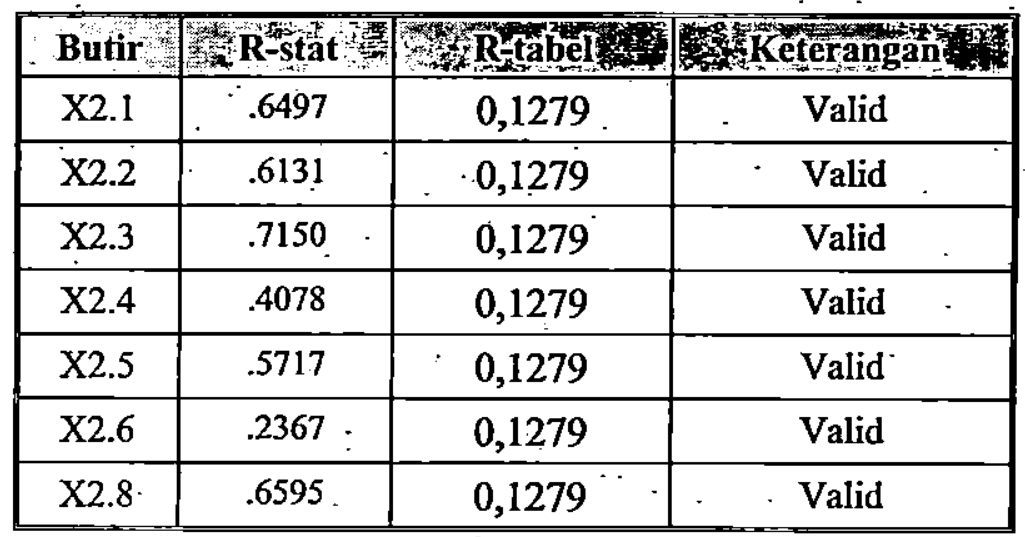


Arief Darmawan: Pengaruh Budaya Organisasi, Motivasi, dan Kompensasi ...

d. Uji Validitas Butir-butir Pertanyaan pada Variabel Motivasi (X3)

Tabel 4

Uji Validitas Variabel Kompensasi (X2)

\begin{tabular}{|c|c|c|c|c|}
\hline Bution & R-stat & 6R-tabel & Koteranga & 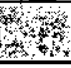 \\
\hline X3.1 &. .5612 & 0,1279 & Valid & \\
\hline $\mathrm{X} 3.2$ & .2573 & 0,1279 & Valid & \\
\hline $\mathrm{X} 3.3$ & .6049 . & 0,1279 & Valid & \\
\hline $\mathrm{X} 3.4$ & .7491 & 0,1279 & Valid & \\
\hline $\mathrm{X} 3.5$ & .6310 & 0,1279 & Valid & \\
\hline X3.6 & .7443 & 0,1279 & Valid & \\
\hline $\mathrm{X} 3.7$ & .5416 & 0,1279 & Valid & : \\
\hline $\mathrm{X} 3.8$ & .5469 & 0,1279 & Valid & \\
\hline X3.9 & .0469 & 0,1279 & Tidak Valic & \\
\hline
\end{tabular}

\section{Uji Reliabilitas}

Uji reliabilitas adalah derajat ketepatan atau tingkat presisi dan tingkat keajegan konsistensi suatu alat ukur. Untuk mengetahui tingkat reliabilitas dari angket, digunakan teknik belah. Selanjutnya dicari koefisien alpha dari cronbach, Mustafa (2000) menyebutkan bahwa untuk mencari koefisien alpha menggunakan rumus sebagai berikut :

$$
\begin{aligned}
\alpha & =\frac{N\left(r_{12}\right)}{1+\left\{\left(r_{12}\right)(n-1)\right\}} \\
r_{12} & =\text { Mean korelasi antar item } \\
n & =\text { Banyaknya item yang di uji }
\end{aligned}
$$

Uji reliabilitas dalam penelitian ini dilakukan dengan program spss 10 for windows.Langkah yang digunakan untuk melakukan pengujian adalah sebagai berikut :

a) Menentukan hipotesis

Ho = Skor butir berkorelasi positif dengan komposit faktor

$\mathrm{H} 1$ = Skor butir berkorelasi positif dengan komposit faktor

b) Menentukan nilai $r$ tabel

$R$ tabel diperoleh dengan mencari df (banyaknya kasus-2) dan menentukan

taraf signifikansi yang akan dipakai.

c) Mencari $r$ hasil

r hasil adalah nilai Alpha (terletak di akhir ouput) 
d) Mengambil keputusan

- Jika $r$ hasil positif, $r$ Alpha $>r$ tabel, maka butir tersebut reliabel

- Jika r hasil positif, $r$ Alpha $<r$ tabel, maka butir tersebut tidak reliabel

Uji coba kuisioner pada 30 responden diperoleh nilai $r=0.2327$, jika dibandingkan dengan nilai Apha maka semua butir dalam pertanyaan adalah reliabel, dimana $\mathrm{r}$ alpha $>\mathrm{r}$ tabel (Lampiran ). Demikian halnya dengan butirbutir pertanyaan pada kuisioner sesungguhnya yang berjumlah 85 responden diperoleh $r$ tabel 0,1279 , sehingga seluruh item pertanyaàn dalam kuisioner adalah reliabel (Tabel 5.)

Tabel 5

Uji Reliabilitas Küisioner

\begin{tabular}{|c|c|c|c|}
\hline Variabel & Nilai Alpha & R-tabel & Keterangan \\
\hline $\mathrm{Y}$ & .9011 & 0,1279 & Reliabel \\
\hline $\mathrm{X} 1$ & .6268 & 0,1279 & Reliabel \\
\hline $\mathrm{X} 2$ & .8118 & 0,1279 & Reliabel \\
\hline $\mathrm{X} 3$ & .7807 & 0,1279 & Reliabel \\
\hline
\end{tabular}

\section{Uji Penyimpangan Asumsi Klasik}

\section{Uji Multikolenieritas}

Untuk menguji ada tidaknya hubungan yang sempurna antara variabel independen dengan variabel idependen yang lain. Untuk mendeteksi adanya multikolenieritas dapat dilihat melalui dua pedoman yaitu :

a. Besaran VIF (Variance Inflation Faktor dan Tolerance)

- Jika besaran VIF berkisar pada angka 1 maka tidak terjadi multikolinearitas.

- Jika angka Tolerance mendekati 1 maka tidak terjadi multikolinearitas

b. Besaran korelasi antar variabel independen

Koefisien korelasi antar variabel independent haruslah lemah (dibawah $0,5)$. Jika korelasi kuat maka terjadi problem multikolenieritas.

Pengujian multikolenieritas dilakukan dengan program SPSS 11 for windows dengan hasil sebagai berikut: 
Arief Darmawan: Pengaruh Budayà Organisași, Motivasi, dan Kompensasi ...

Tabel 6

Uji Multikolenieritas (Coefficients)

\begin{tabular}{|c|c|c|c|}
\hline & & Collinearity Statistics & \\
\hline Model & & Tolerance & VIF \\
\hline 11 & $\mathrm{X} 1$. & .555 & 1.800 \\
\hline & $\mathrm{X} 2$ & .944 & 1.059 \\
\hline & $\mathrm{X} 3$ & .569 & 1.756 \\
\hline
\end{tabular}

a Dependent Variable: $Y$

Tabel 7

Uji Multikolenieritas (Coefficient Correlations)

\begin{tabular}{|c|l|c|c|c|c|}
\hline Model & & & $\mathbf{X 3}$ & $\mathbf{X} 2$ & $\mathbf{X 1}$ \\
\hline 1 & Correlations & $\mathrm{X} 3$ & 1.000 & -.176 & -.656 \\
\hline & & $\mathrm{X} 2$ & -.176 & 1.000 & .234 \\
\hline & & $\mathrm{X} 1$ & -.656 & .234 & 1.000 \\
\hline & Covariances & $\mathrm{X} 3$ & $1.544 \mathrm{E}-02$ & $-1.384 \mathrm{E}-03$ & $-1.163 \mathrm{E}-02$ \\
\hline & & $\mathrm{X} 2$ & $-1.384 \mathrm{E}-03$ & $3.987 \mathrm{E}-03$ & $2.113 \mathrm{E}-03$ \\
\hline & & $\mathrm{X} 1$ & $-1.163 \mathrm{E}-02$ & $2.113 \mathrm{E}-03$ & $2.038 \mathrm{E}-02$ \\
\hline
\end{tabular}

a Dependent Variable: $Y$

Pada bagian Coefficient dari tabel di atas nampak bahwa untuk ketiga variabel masing-masing mempunyai nilai VIF : budaya (1.800), kornpensasi (1.059) dan motivasi (1.756). Angka tersebut menunjukan bahwa terdapat multikolinearitas pada variabel budaya dan motivasi karena angkanya jauh diatas angka 1. Begitupun juga jika dilihat dari nilai tolerance pada masing-masing variabel yaitu budaya (0.555), kompensasi (0.944) dan motivasi (0.569), maka budaya dan motivasi terdapat problem multikolenieritas karena nilai tolerancenya jauh dibawah angka 1. Pada tabel bagian kedua juga memperlihatkan bahwa terdapat korelasi yang kuat antara budaya dan motivasi dimana angka korelasinya sebesar 0.656 , Syarat suatu model regrresi terbebas dari asumsi multikolenieritas adalah korelasi antarvariabel independen harus lemah:(dibawah 0,5 ). Salah satu metode untuk menghilangkan pengaruh multikoleniaritas adalah dengan menghilangkan atau mengeluarkan salah satu variabel dalam model yang saling berkolerasi kuat yaitu budaya dan motivasi. Dengan menghilangkan variabel budaya diperoleh output seperti terlihat dalam tabel berịkut ini : 
Tabel 8

Uji Multikolenieritas (Coefficients)

\begin{tabular}{|c|c|c|c|}
\hline & & Collinearity Statistics & \\
\hline Model & & $\cdots \quad$ Tolerance & VIF \\
\hline 1 & $\mathrm{X} 2$ & .999 & 1.001 \\
\hline$\therefore$ & X3 & .999 & 1.001 \\
\hline
\end{tabular}

a Dependent Variable: $X$

Tabel 9

Uji Multikolenieritas (Coefficient Correlations)

\begin{tabular}{|c|c|c|c|c|}
\hline Model & & & $\mathbf{X 3}$ & $\mathbf{X 2}$ \\
\hline 1 & Correlations & $\mathrm{X} 3$ & 1.000 & -.031 \\
\hline &. & $\mathrm{X} 2$ & -.031 & 1.000 \\
\hline & Covariances & $\mathrm{X} 3$ & $8.701 \mathrm{E}-03$ & $-1.756 \mathrm{E}-04$ \\
\hline & & $\mathrm{X} 2$ & $-1.756 \mathrm{E}-04$ & $3.726 \mathrm{E}-03$ \\
\hline
\end{tabular}

a Dependent Variable: $Y$

Pada bagian Coeficient dari tabel diatas nampak bahwa nilai VIF dari variabel kompensasi sebesar (1.001) dan motivasi (1.001). Angka tersebut menunjukan bahwa kedua variabel tersebut terbebas dari problem multikolinearitas karena angkanya mendekati angka 1. Begitupun juga jika dilihat dari nilai tolerance variebel kompensasi (0.999) dan motivasi (0.999), maka kompensasi dan motivasi tidak.terdapat problem multikolenieritas karena nilai tolerancenya jauh dibawah angka 1. Pada tabel bagian kedua memperlihatkan bahwa korelasi antara kompensasi dan motivasi adalah lemah yaitu sebesar dimana angka korelasinya sebesar 0.031 , jauh dibawah 0,5 .

\section{Uji Heteroskedastisitas}

Uji heteroskedastisitas digunakan untuk menguji apakah terjadi ketidaksamaan varians dari residual dari suatu pengamatan ke pengamatan lain. Jika varian dari residual dari suatu pengamatan ke pengamatan lain tetap, maka disebut homoskedastisitas. Namun apabila variansnya berbeda di sebut heteroskedastisias. Uji heteskedastisitas dạlam penelitian ini menggunakan SPSS 10. 
Arief Darmawan: Pengaruh Budaya Organisasi, Motivasi, dan Kompensasi ...

\section{Scatterplot}

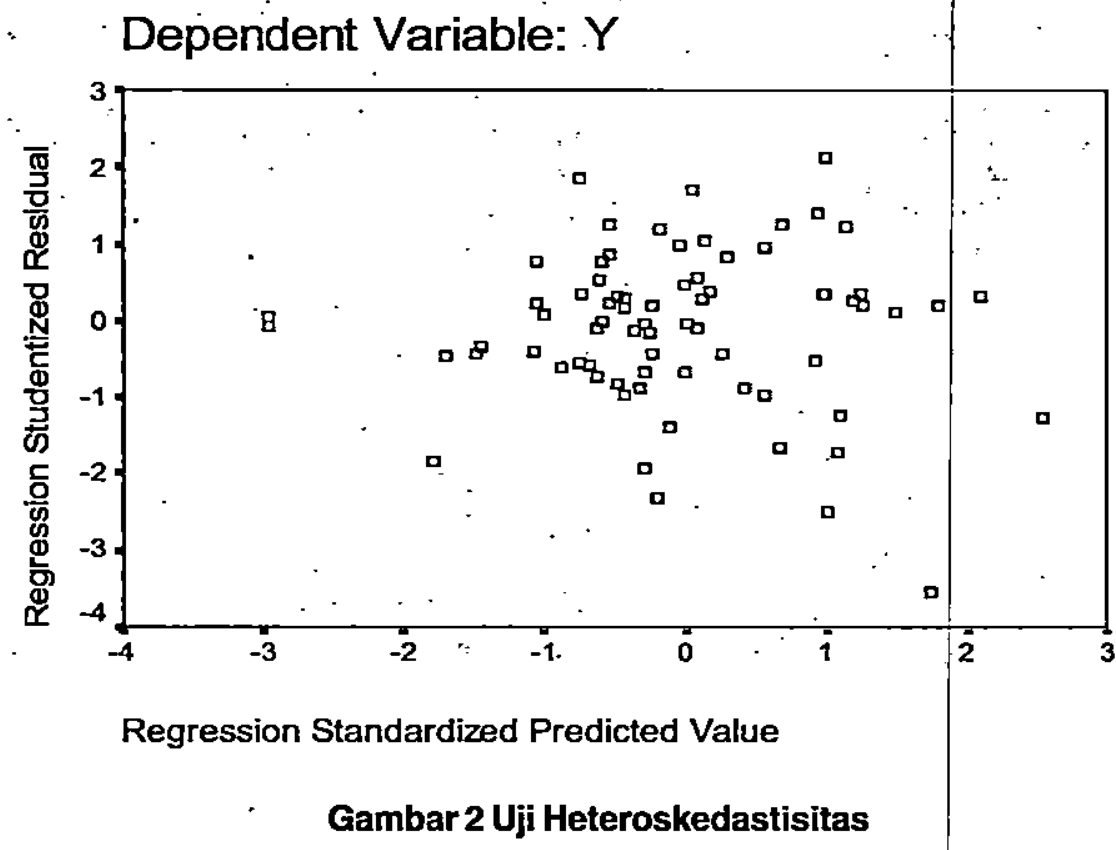

Dari grafik diatas terlihat bahwa titik menyebar secara acak dan tidak membentuk suatu pola tertentu secara jelas, dimana titik-titik tersebut tersebar di atas maupun di bawah angka 0 pada sumbu $Y$ sehingga bisa dikatakan model regresi yang digunakan terbebas dari heteroskedastisitas.

\section{Analisis.Inferensial}

Dalam penielitian ini, metode analisis yang dipergunakan adalah regresi linier berganda: Karena variebel budaya (X1) dan motivasi (X3) terdapat korelasi yang -kuat atau terkena problem multikolinieritas maka variabel budaya dikelluarkan dari model penelitian sehingga model persamaan linear adalah:

$Y=b o++b 2 X 2+b 3 X 3$

Keterangan:

$Y=$ Produktivitas

$X 2=$ Kompensasi

$\mathbf{X}=$ Motivasi

$\beta_{0}, \beta_{1}, \beta_{2}, \beta_{3}$, Koefisien penjelas masing-masing input nilai parameter.

Hasil regresi selengkapnya terangkum dalam tabel berikut ini: 
Tabel 10

Hasil Regresi

\begin{tabular}{|c|c|c|c|c|c|}
\hline $\begin{array}{l}\text { Variabel } \\
\text { penjelás }\end{array}$ & $\begin{array}{l}\text { Koefisien } \\
\text { regresi }\end{array}$ & standar & $\begin{array}{c}T \\
\text { statistiki }\end{array}$ & $\begin{array}{l}\text { Koef Koralasi } \\
\text { - Parsial }\end{array}$ & $\begin{array}{c}\text { Koế } \\
\text { Determinasi } \\
\text { Parsial }\end{array}$ \\
\hline Konstata & 2.432 & .418 & 5.811 & & \\
\hline $\mathbf{X} 2$ & -.03256 & .061 & -.533 & $\therefore .059$ & 0.0035 \\
\hline $\mathbf{X} 3$ & .424 & .093 & 4.545 & .449 & 0.2016 \\
\hline $\mathbf{R}^{2}$ & -.202 & & & - & \\
\hline $\mathbf{R}$ & .450 & & & . & . \\
\hline F -Stat & 10.406 & & & & $\because$ \\
\hline
\end{tabular}

Sumber: hasil pengolahan data SPSS

Persamaan regresi berganda yang dapat dibentuk berdasarkan print out data adalah sebagai berikut:

$$
Y=2,432-0.03256 \times 2+0.424 \times 3
$$

Daripersamaan regresi tersebut interpretasi koefisien variabel regresi dapat dijelaskan sebagai berikut:

1) Nilai koefisien konstata menunjukan angka sebesar2,432 Secarastafistik hal ini bermakna jika variabel independen yaiti ikompensasi (X2) can Motivasi (X3) dianggap tidak ada (nol) maka produkfifitas kejja karyawan administratif Ull adalah sebesar $2,5 \%$

2) Koefisien regresi variabe! Kompensasi (X2) adalath sebesar 0.0325 dan bertanda negatif. Artinya, terdapat hubungan yang berilawanamarah antara kompensasij dan produktifitas keja karyawan administrafif Ull Sehingga jika terjadi kenaikan kompensasi sebesar $1 \%$ makk prođukffitas kerja karyawan administratif Uil akan turun sebesar 0.0325\%

3) Koefisien regresi variabel Motivasi (X3) adakahsebesar Q.424 dan bentandar positif. Artinya, terdapat hubungan searah antara mofyrasi dan produkfifitas kerja karyawan administratif Ull. Sehingga jika tejjadi kenaikan motivasj sebesar $1 \%$ maka produktifitas keja karyawan administrafif Ull aken maik sebesar $0.44 \%$

\section{Koefisien Determiniasi Berganda (R Square) dan Koefisien Korelasi Berganda}

Daì hasil pengolahan data dengan menggunakan program SPSS, ciperoleh nilai koefisien determinasi berganda ( $\left.R^{2}\right)$ sebesar 0.202 . Secara statistik iñ 
bermakna bahwa variabel budaya kerja (X1), kompensasi (X2) dan motivasi (X3) secara bersama-sama hanya mampu menjelaskan variasi variabel produktifitas kerja $(Y)$ sebesar 20,2\% dan sisanya dipengaruhi oleh variabel lain diluar model yang dipergunakan. Sedangkan nilai koefisien korelasi berganda menunjukan angka sebesar 0.451 . Artinya, korelasi antara budaya kerja (X1), kompensasi (X2) dan motivasi (X5) dan produktifitas kerja (Y) adalah sebesar $45 \%$ dan dapat dikatakan bahwa korelasi antara variabel dependen dan variabel independen adalah lemah.

\section{Uji Hipotesis Koefisien Regresi Secara Parsial ( Uji T)}

1) Untuk mengetahui pengaruh variabel independen ternadap variabel dependen secara parsial digunakan uji t-statistik.

Dengan tingkat alpha $5 \%$ dan df $=82$ pengujian satu sisi (one tail significant), diperoleh t-tabel sebesar 1.645. Nilai t-hitung dari ketiga variabel independen masing-masing adalah:

$\S$ Budaya Organisasi (X1): -0.296

$\S$ Kompensasi $(X 2):-0.585$

$\S$ Motivasi (X3) : 3.606

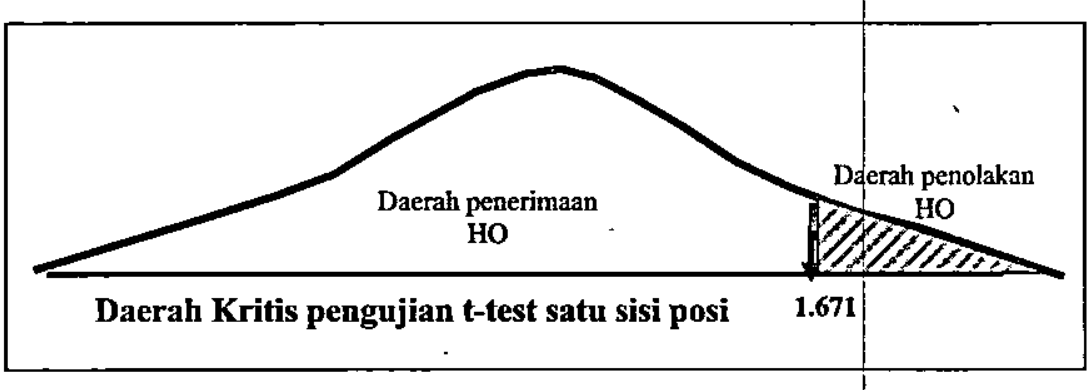

Gambar 4 Daerah Kritis pengujian t-test satu sisi positif

2) Pengambilan keputusan

Jika dilihat dari besarnya nilai t-statistik pada ketiga variabel independen, tampak bahwa secara parsial hanya variabel motivasi $(X 3)$ yang nilai tstatistik $>$ nilai t-tabel sehingga masuk dalam wilayah penolakan $\mathrm{Ho}$, artinya secara statistik variabel motivasi berpengaruh signifikan terhadap produktifitas karyawan administratif UII. Sementara itu dua variabel independen yang lainnya yaitu budaya dan kompensasi mempunyai nilai t-statistik masing masing adalah -0.296 dan 0.585 , artinya angka t-statistik< $\mathrm{t}$-tabel sehingga masuk dalam daerah penerimaan $\mathrm{Ho}$. Hal ini membuktikan variabel budaya $(X 1)$ dan kompensasi (X2) secara parsial tidak mempunyai signifikasi pengaruh terhadap produktifitas karyawan administratif Ull. Dengan demikian, hasil pengujian ini menyanggah hipötesis pertama dari penelitian yang menyebutkan bahwa variabel budaya (X1) dan kompensasi (X2) dan motivasi (X3) secara parsial mempunyai. pengaruh signifikan terhadap produktifitas karyawan administratif UII. 


\section{Uji Hipotesis Koefisien Regresi Secara Serempak (Uji F)}

Untuk melihat apakah seluruh variabel independen berpengaruh terhadap variabel dependen secara serempak dilakukan uji F-statistik, adapun langkahlangkah pengujiannya adalah:

1) Menetukan hipotesis

Ho: $1=2=3=0$, variabel-variabel independen secara bersama-sama tidak mempengaruhi variabel dependen.

Ha : $1^{1} 2^{1} 3^{1} 0$, variabel-variabel independen secara bersama-sama mempengaruhi variabel dependennya.

2) Menetapkan daerah kritis melalui F-tabel dan mencari nilai F-hitung Dengan menggunakan $=5 \%$ diperoleh besarnya $F$ tabel $(k-1, n-k)$ adalah 3,07 sementara itu nilai $F$ hitung adalah 6.889 .

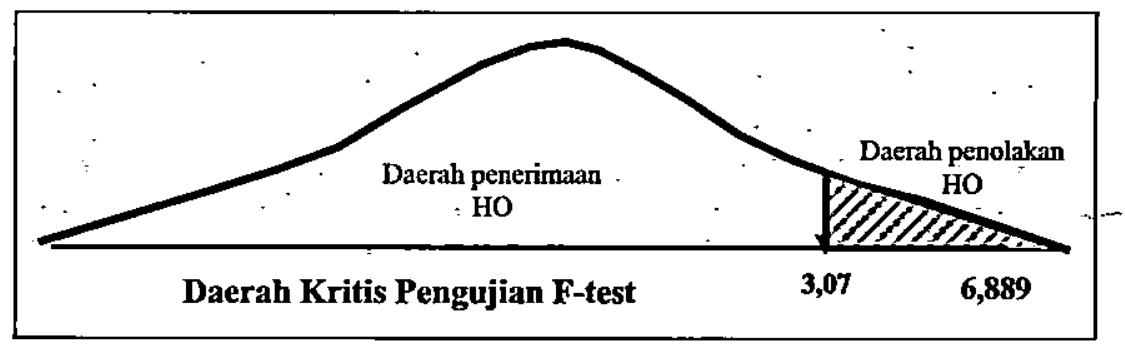

\section{Gambar 5}

3) Pengambilan keputusan

Karena nilai F-hitung > F-tabel, maka F-hitung berada di daerah penolakan Ho, sehingga secara serentak variabel independen yaitu budaya kerja (X1), kompensasi (X2) dan motivasi (X3) berpengaruh secara signifikan terhadap produktifitas kerja $(Y)$. Dengan demikian, hasil pengujian ini mendukung hipotesis penelitian yang menyebutkan bahwa budaya kerja (X1), kompensasi (X2) dan motivasi (X3) secara bersama-sama berpenganuh signifikan terhadap produktifitas kerja $(Y)$

\section{Uji Koefisien Determinasi dan Korelasi Secara Parsial}

Untuk mengetahui tingginya derajat hubungan antara satu variabel $(X)$ terhadap variabel $(Y)$ digunakan analisis korelasi parsial. Sementara itu untuk mengukur seberapa besar prosentase pengaruh secara parsial antara satu variabel $(X)$ terhadap variabel $(Y)$ digunakan analisis koefisien determinasi parsial.

1) Korelasi antara budaya ( $X 1$ 1) dan produktifitas Karyawan( $Y$ ).

Nilai koefisien determinasi parsial dari variabel budaya ădalah sebesar 0.0011 , artinya secara parsial variabel budaya menyumbang pengaruh terhadap produktifitas karyawan administratif Ull sebesar $0,1 \%$. 
Arief Darmawan: Pengaruh Büdaya Organisasi, Motivasii, dan Kompensasi ...

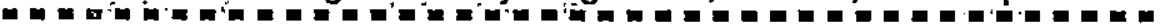

2) Koŕelasi antara variabel Kompensasi (X2) dan Produktivitas Karyawan (Y)

'Nilai koefisièn determinasi paršial dari variabel kompensasi (X2) adalah sebesar 0.0043 , artinya secara parsial kompensasi menyumbang pengaruh terhadap produktifitas karyawan administratif UII sebesar $0,4 \%$.

3) Korelasi antara variabel motivasi (X3) dan produktifitas karyawan $(Y)$. Nilai koefisien determinasi parsial dari variabel motiväsi $(X 3)$ adalah sebesar 0.1281 , artinya secara parsial variabel motivasi menyumbang pengaruh terhadap produktifitas karyawan administratif Üll sebesar $12,8 \%$. Dari hasil analisis korelasi dan pengaruh secara parsial diatas, tampak bahwa variabel independen yang paling dominan pengaruhnya terhadap produktifitas karyawan administratif UII $(Y)$ adalah variabel motivasi $(X 3)$ dengan pengaruh sebesar $12,8 \%$. Selengkapnya disajikan dalam tabel berikut ini:

Tabel 11

Dominasi Pengaruh Variabel Independen Terhadap. Variabel Dependen

\begin{tabular}{|l|l|l|l|}
\hline Peringkat & Variabel independen & \multicolumn{2}{|c|}{ Prosentase pengaruh } \\
\hline 1 & Budaya (X1) & $0,01 \%$ & \\
\hline 2 & Kompensasi (X2) & $0,04 \%$ & \\
\hline 3 & Motivasi (X3) & $12,8 \%$ & \\
\hline
\end{tabular}

F. KESIMPULAN

a. Secara simultan melalui uji f diketahui bahwa variabel Budaya Organisasi, kompensasi dan Motivasi secara bersama-sama mempunyai pengaruh terhadap produktivitas kerja. Hal itu terlihat dari nilai uji f; dimana nilai $f$ hitung $=6,889$ diatas nilai $f$ tabel $=3,07$

Nilai koefisien determinasi sebesar $20,3 \%$, hal ini menunjukkan bahwa variasi produktivitas kerja karyawan administratif hanya bisa dipengaruhi oleh variabel budaya organisasi, kompensasi, dan motivasi sebesar 20,3 $\%$. Sedangkan sisanya $(100 \%-20,3 \%=79,7 \%)$ dipengaruhi oleh variabel lain diluar model yang dipergunakan.

b. Kompensasi berpengaruh terhadap produktivitas kerja tetapi negatif, sehingga hipotesis yang menyatakan bahwa variabel kompensasi dengan variabel produktivitas kerja berpengaruh positif tidak terbukti.

c. Motivasi memiliki pengaruh positif, dan signifikan dengan produktivitas kerja. Sehingga hipotesis yang menyatakan báhwa variabel motivasi dengan produktivitas kerja berpengaruh positif dapat terbukti 
d. Hasil uji korelasi menunjukkan bahwa variabel yang paling kuat dan signifikan berpengaruh terhadap produktivitas kerja karyawan administratif di Universitas Islam Indonesia adalah motivasi.

\section{DAFTAR PUSTAKA}

Anoraga, Pandji dan Sri Suyati. "Perilaku Organisas? PT Dunia Pustaka Jaya., Cetakan pertama., 1995

Ariyanti, Rahayuningsih Deasy, Analisis Budaya Organisasi, Kepuasan Gaji, Kepuasan Kerja, Motivasi dalam Produktivitas Kerja Staf Akunting: Studi Empiris, Jumal Usahawan No. 12/TH XXXV Desember 2006

As'ad, Moh, Psikologi Industri. Cetakan Kedua. Jogjakarta, Liberti

Bruce, Anne. How to Motivate Every Employee :24 Point Penting Seputar Peningkatan Produktivitas di tempat Kerja, Acuan Praktis Meningkatkan kerja Perusahaan., PT Buana llmu Populer. 2003

Budiyati, Utik. Pengaruh Budaya Kerja, Kompensasi dan Motivasi terhadap Kinerja Karyawan Universitas Ahmad Dahlan Jogjakarta, Tesis Magister Manajemen, 2006

Djarwanto, dan Pangestu Subagyo, Statistik Induktif, BPFE 2000

Ghazali, Imam, Analisis Multivariate dengan Program SPSS. Penerbitan UNDIP. 2004

.Haryani. Hubungan Kepuasan Kerja Dengan Produktivitas Kerja di Perusahaan Tenun Setagen Ibu Wasil. Jurnal Ekonomi Manajemen dan Akuntansi. No 8. Th.5, Agustus 1998

Hanidoko, T.Hani, Manajemen Personalia dan Sumber Daya Manusia. BPFE. 2000

Heidjerachman, dan Suad Husnan. Manajemen Personalia, BPFE. 2002

Hasibuan Malayu S.P, Organisasi dan Motivasi, Dasar Peningkataan Produktivitas, Cetakan Pertama. Bumi Aksara 1996.

Kuncoro, Mudrajat, Metode Riset untuk Bisnis dan Ekonomi, Erlangga. 2003

Lako, Andreas. Budaya Organisasi dan Kesuksesan Kinerja Éknomi, Kajian Bisnis STIE Widya Wiwaha Jogjakarta, 2002 Latham, Gary P, dan Kenneth N Wexley, Increasing Prooductivity Through Performance Appraisar Addison Wesley publishing Company. Second Edition. 1994) 
Arief Darmawan: Pengaruh Budaya Organisasi, Motivasi, dan Kompensasi ...

Latham, Gary P, dan Kenineth N Wexley, Increasing Prooductivity Through Performance Appraisar' Addision Wesley publishing Company. Second Edition. 1994)

Mulyadi, Suyono, Analisis Faktor-faktor Motivasi Dalam Produktivitas Kerja Karyawan Perguruan Tinggi Swasta Kopertis Wilayah VPropinsi Daerah Istimewa Yogyakarta, Tesis Program MM UII, 1998

Mustafa, Zainal, Pengantar Statistik Terapan UntukEkonomi, Ull. Jogjakarta, 1995

Nawawi, Hadari, Manajemen Sumber Daya Manusia, Gadjah Mada Press, 2005

Pumama, Nursya'bani, Membangun Keunggulan Bersaing Melalui Integrasi Perencanaan Strategik dan Perencanaan SDM, Jumal Usahawan No. 07.TH XXIX Juli 2000

Reksohadiprojo, Sukanto, T.Hani Handoko; Organisasi Perusahaan, BPFE 1997

Robbin, Stephen P, Terjemahan, Prilaku Organisasi, Jilid I, PT Prenhallindo Jakarta, 2001

Robbin, Stephen P, Terjemahan, Prilaku Organisasi, Jilid II, PT Prenhallindo Jakarta, 2001

Schuler, Randall.S, Susan E Jackson, Terjemahan, Manajemen Sumber Daya Manusia Menghadapi Abad 21, Jilid I, Erlangga, 1999

Schuler, Randall.S, Susan E Jackson, Terjemahan, Manajemen Sumber Daya Manusia Menghadapi Abad 21, Jilid Il, Erlangga, 1999

Siagian, Sondang P. "Kiat Meningkatkan Produktivitas Kerja". Penerbit Rineka Cipta, 2002

Sekaran, Uma, Research Method for Business: A Skill Building Approach. Fourt Edition, John Willey \& Son, New York, 2003

Swastha, Basu dan Sukotjo, Manajemen Sumber Daya Manusia, BPFE, 1998

Supardi, Metodologi Penelitian Ekonomi dan Bisnis, UII Press, Jogjakarta, 2005

Tampubolon, Manahan,. Hubungan Loyalitas Karyawan dengan Kelangsungan Organisasi (Survei di STIETri.Sakti ), Jurnal Widya Ekonomika, Tahun V, No1 Januari-Juni, 2004

UU No. 2 th 1989, Gita Setia, Balai Pengembangan Kegiatan Belajar, Jaya Giri lembang, 1989 